В.І. Коновець ${ }^{1}$, Н.Б. Смиринська ${ }^{2}$

${ }^{1}$ Інститут Військово-Морських Сил Національного університету

“Одеська морська академія”, Одеса

${ }^{2}$ Науково-дослідний иенттр Збройних Сил Украӥни “Державний океанаріум”, Одеса

\title{
ШЛЯХИ ПІДВИЩЕННЯ ПРОІНФОРМОВАНОСТІ ПРО МОРСЬКУ ОБСТАНОВКУ ЗА РАХУНОК ІНТЕГРАЦІЇ КОРАБЕЛЬНИХ НАВІГАЦІЙНИХ РАДІОЛОКАЦІЙНИХ СТАНЦІЙ В СИСТЕМУ ВИСВІТЛЕННЯ НАДВОДНОЇ ОБСТАНОВКИ
}

В статті наведено результати аналізу питань практичної інтеграџії даних від навігаційних РЛС корабельної компоненти ВМС ЗС України у систему висвітлення надводної обстановки. Із врахуванням иього аналізу розроблено рекомендацій щзодо вибору варіантів комплектації навігаційних РЛС, щзо плануються до встановлення на сучасні та перспективні морські платформи з метою забезпечення їх подальшої інтеграції у систему висвітлення надводної обстановки.

Ключові слова: проінформованість (обізнаність) про морську обстановку, система висвітлення надводної обстановки, навігаційні РЛС, система автоматичної радіолокаційної прокладки (CAPП/ARPA), повідомлення обміну інформацією, ВМС ЗС України.

\section{Вступ}

Постановка проблеми. Актуальність досліджень обумовлена необхідністю створення сучасної системи висвітлення надводної обстановки 3 метою забезпечення реалізації Указу Президента України від 14 березня 2016 року № 92/2016 про введення в дію Рішення Ради національної безпеки і оборони України від 4 березня 2016 року “Про Концепцію розвитку сектору безпеки і оборони України” [1] та “Стратегії інтегрованого управління кордонами на період до 2025 року” (далі - Стратегія), яка затверджена розпорядженням Кабінету Міністрів України від 24 липня 2019 р. № 687-р [2], однією із стратегічних цілей якою $є$ контроль за морською обстановкою, що забезпечує оперативне реагування на ії зміни, що в свою чергу включає завдання забезпечення розвитку спроможності системи висвітлення морської обстановки, а саме:

- збільшення зони покриття засобів спостереження;

- удосконалення системи збору, узагальнення, аналізу та обміну даними про обстановку тощо.

Стратегією визначені проблеми управління кордонами однією із яких є:

- нездатність систем висвітлення морської обстановки у Чорному та Азовському морях забезпечувати заінтересовані суб'єкти інтегрованого управління кордонами повною оперативною інформацією про ситуацію на морі, зокрема під час проведення пошуково-рятувальних операцій [2].

Таким чином, створення сучасної системи висвітлення морської обстановки дозволить забезпе- чити контроль над зоною національних інтересів i готовності до контролю тимчасово окупованих територій в акваторії Чорного та Азовського морів (за внутрішніми морськими водами, територіальним морем, прилеглою зоною та виключною (морською) економічною зоною), безпеки мореплавства, охорони людського життя на морі і рятування людей, майна і суден та в найкоротший термін відновлення системи охорони морських баз та узбережжя, а також ключових об'єктів інфраструктури в зоні відповідальності Військово-Морських Сил Збройних Сил України (далі - ВМС ЗС України).

3 метою підвищення обізнаності про морську обстановку шляхом нарощування кількості сенсорів, що $є$ постачальниками даних для системи висвітлення надводної обстановки, яка є основною ії складової, велику актуальність набуває питання залучення до вказаної системи навігаційних РЛС (далі НРЛС) кораблів та суден ВМС ЗС України.

Аналіз останніх досліджень і публікацій. Аналіз останніх досліджень та публікацій [3-11], а також досвід побудови та організації систем спостереження за надводною обстановкою провідних країн світу свідчить про те, що на сьогодні ці системи $є$ основою побудови загальної систем морської безпеки цих країн, включаючи, зазвичай, увесь спектр джерел отримання інформації щодо морської безпеки (Maritime Security Information) для забезпечення повної проінформованості (обізнаності) про морську обстановку (Maritime Situational Awareness) 3 метою набуття спроможності до повної обізнаності у морській сфері держави (Maritime Domain Awareness). 
Постійний моніторинг критичних факторів дозволяє підтримувати матрицю оцінки загрози в актуальному стані, адекватно та оперативно реагувати на загрози та виклики національній безпеці 3 морського напрямку. Повноцінний моніторинг, що мав би забезпечувати ланку прийняття рішень вичерпним набором інформації, неможливий без включення до складу системи висвітлення обстановки всього спектру засобів спостереження. Проте, як свідчить аналіз вказаних систем провідних країн, основною їх ланкою залишаються радіолокаційні засоби.

Для забезпечення максимальної повноти та достовірності висвітлення надводної обстановки система висвітлення обстановки повинна отримувати дані від РЛС корабельного, повітряного, космічного, берегового стаціонарного та мобільного базування.

Зважаючи на доволі різноманітний парк радіолокаційної техніки, що перебуває на озброєнні підрозділів ВМС ЗС України на сучасному етапі, актуально постає питання іiі повноцінної інтеграції в систему висвітлення обстановки.

Метою статті $є$ аналіз питань практичної інтеграції даних від НРЛС корабельної компоненти ВМС 3С України у систему висвітлення надводної обстановки (далі - CВНО), та розробці рекомендацій щодо вибору варіантів комплектації НРЛС, що плануються до встановлення на сучасні та перспективні платформи як в процесі модернізації, так і в ході проектування, з метою забезпечення їх подальшої інтеграції у СВНО.

\section{Виклад основного матеріалу}

Радіолокаційне спостереження за надводною обстановкою $є$ однією 3 найважливіших технічних складових системи спостереження, порівняно 3 iнформацією, що може бути отримана від інших технічних сенсорів у складі системи (зокрема, оптичних, оптико-електронних, транспондерів системи AIC тощо), оскільки:

- дозволяє контролювати водну поверхню безперервно (24/7/365);

- $\epsilon$ активною незалежною системою спостереження (тобто не залежить від ввімкнення/вимкнення спеціальних відповідачів на об'єкті спостереження);

- має відносно велику дальність дії;

- мало залежне від погодних умов, тощо.

Корабельні НРЛС, які плануються до інтеграції до складу СВНО у якості радар-сенсорів, повинні забезпечувати наступні вбудовані базові функції:

- захоплення цілі на автосупроводження;

- автосупроводження цілей;

- видача інформаційних повідомлень (формуляру) 3 параметрами руху цілей до зовнішніх пристроїв.

Відсутність реалізації у НРЛС, що розглядається підтримки будь-якої з наведених функції робить недоцільним включення іiї до СВНО в якості повноцінного сенсора.

Про реалізацію підтримки згаданих вище функцій заздалегідь дозволяє судити факт наявності чи відсутності у складі НРЛС вбудованої системи автоматичної радіолокаційної прокладки (далі CAPП/ ARPA).

CAPП/ARPA - це допоміжні комп'ютерні системи обробки даних від радару, які призначені для автоматичного відстеження цілей, видачі параметрів цілей на екран НРЛС та у зовнішні пристрої, надання додаткової навігаційної інформації, що призначена для вирішення задач розходження суден.

Вимоги до САРП викладені в стандартах Міжнародної Морської Організації (International Maritime Organization, далі - IMO) на створення суднових/корабельних НРЛС, зокрема, Резолюція IMO А.823(19) “Експлуатаційні вимоги до системи автоматичної радіолокаційної прокладки (САРП)” [12], Резолюція IMO MSC.192(79) Додаток 34 “Переглянуті експлуатаційні вимоги до радіолокаційного обладнання” [13], стандарт IEC 62388:2013 “Апаратура і системи морської навігації та радіозв'язку. Радіолокаційні суднові станції. Експлуатаційні вимоги, методи випробування та необхідні результати випробувань” [14], який визначає мінімальні операційні та експлуатаційні вимоги, методи випробувань та необхідні результати випробувань, що відповідають стандартам експлуатаційних характеристик, що не поступаються стандартам, прийнятим IMO у Резолюції MSC.192(79).

В системі САРП повинні забезпечуватися умови для швидкого визначення пеленга та відстані до будь-якого об'єкту в зоні огляду. Необхідно, щоб режим автосупроводження дозволяв за період часу, що не перевищує однієї хвилини після захоплення цілі, представити дані щодо напрямку руху об'єкта, i на протязі трьох хвилин з початку супроводу вивести на екран прогноз руху відповідно до обставин. Також, оператор повинен мати можливість обрати будь-яку із взятих на супроводження цілей для отримання додаткової інформації.

Ідентифікація супроводжуваних цілей зазвичай виконується САРП шляхом автоматичного присвоєнням їй унікального номера в межах від 1 до N (максимальне число цілей, що супроводжуються).

Умовно класифікувати всі наявні у ВМС ЗС України корабельні НРЛС з вбудованим модулем САРП можливо наступним чином:

1. РЛС з САРП для суден, що підпадають під дію конвенцій Міжнародної Морської Організації (IMO);

2. РЛС з САРП для маломірного флоту.

Наведена класифікація базується на відмінності у вимогах до стандартів виконання цих РЛС. На 
даний час на кораблях та суднах ВМС ЗС України використовуються РЛС обох вказаних вище типів.

Також, варто зазначити, що НРЛС, якими обладнані морські платформи ВМС ЗС України на сьогодні побудовані відповідно до вимог стандартів IEC 60872 [15] та IEC 60936 [16], які є застарілими та замінені на стандарт IEC 62388:2013 [14], згаданий вище.

\section{Питання інтеграції корабельних НРЛС у CBHO}

Задача 3 під'єднання корабельних НРЛС до СВНО не є тривіальною. По відношенню до НРЛС, СВНО є віддаленим споживачем 3 доступом через радіоканал. Не варто розраховувати на те, що вбудоване спеціалізоване програмне забезпечення чи штатні інтерфейси наявних НРЛС можливо якимось чином модернізувати чи оптимізувати під задачі CBHO чи обмеження, що накладаються особливостями радіоканалу. Таким чином, основні зусилля 3 інтеграції повинні бути спрямовані на адаптацію існуючих інформаційних виходів НРЛС. 3 цією метою необхідно застосовувати готові або розроблені індивідуально зовнішні конвертори інтерфейсів. 3 урахуванням невисокої вартості розробки та виробництва, з огляду на широкий типоряд наявних НРЛС та 3 метою досягнення більшої гнучкості та максимальної повноти використання вихідних даних НРЛС, пріоритет доцільно віддати варіанту індивідуальної розробки конверторних пристроїв.

\section{Питання узгодження протоколів та форматів обміну інформації для видачі від НРлС у СBHO}

3 боку видачі інформаційних повідомлень (формулярів) 3 параметрами руху цілей до зовнішніх пристроїв, ситуація для існуючих НРЛС першого умовного типу (що підпадають під дію конвенцій IMO) наступна.

Виведення інформації САРП про цілі, що супроводжуються, в зовнішні пристрої виконується у відповідності до загальноприйнятих вимог стандарту IEC 61162-1(2016) “Морське навігаційне обладнання і засоби радіозв'язку. Цифрові інтерфейси. Частина 1. Одне джерело і кілька приймачів повідомлень” [17].

Інформацію про цілі, що супроводжуються САРП, несуть наступні стандартні повідомлення с даними: TLB, TLL, TTM, TTD. Розглянемо більш детально призначення вказаних наборів даних.

TLB - Target labe - ідентифікуючі мітки для цілей, що супроводжуються. Це повідомлення використовується для передачі міток цілей, що супроводжуються, на пристрій, який здійснює безпосереднє супроводження цілей, отримуючи дані, зокрема, через повідомлення типу ТТМ. Це повідомлення дозволяє пристрою відображення, наприклад ECDIS
(Electronic Chart Display and Information System морська інформаційна навігаційно-картографічна система), відображати цілі, що відслідковуються, 3 їх ідентифікуючими мітками.

TLL - Target latitude and longitude - довгота та широта цілі: повідомлення, що містить дані про номер цілі, їі ім'я, позицію (довгота та широта) та маркер часу, та використовується в системах супроводження цілей.

TTM - Tracked target message - повідомлення про ціль, що супроводжується. Це повідомлення, що містить дані про позицію цілі, що відслідковується, відносно позиції власного судна.

Розглянемо приклад формату повідомлення TTM (рис. 1):

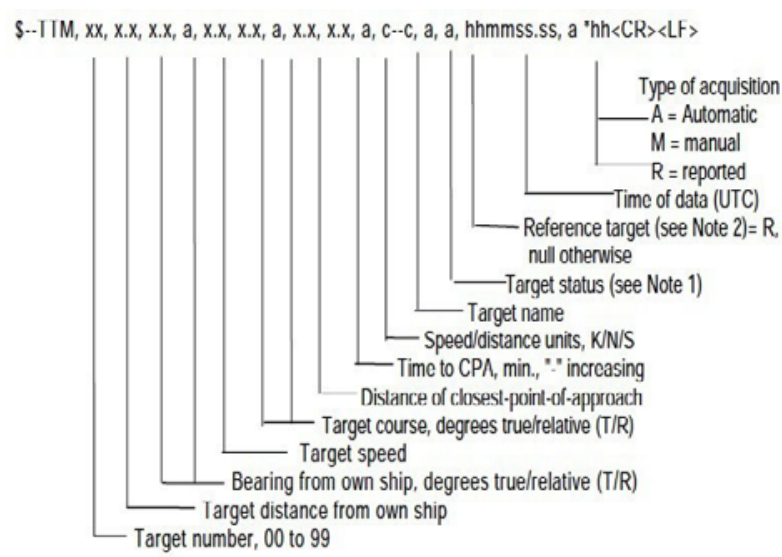

Рис. 1. Формат повідомлення ТТМ Джерело: [17, С. 116].

Кожен рядок починається символом '\$'. Дані складаються 3 параметрів, розділених комами. Тип i склад параметрів залежить від ідентифікатора рядка. “ $<\mathrm{CR}><\mathrm{LF}>$ " позначає кінець рядка; "х.х,a,c---с...” данні; “*hh” - поле перевірки контрольної суми повідомлення.

Примітки (Note) вказані на рис. 1 визначають наступне:

Примітка 1: статус цілі:

$\mathrm{L}=$ Втрачена, відстежена ціль втрачена;

$\mathrm{Q}=$ Запит, ціль у процесі захоплення;

$\mathrm{T}=$ Відстежується.

Примітка 2: опорна (референтна) ціль: встановлюється на “R”, якщо ціль є опорною, відносно якої визначаються координати або швидкість власного корабля, інакше нуль.

TTD - Tracked target data - дані цілей, що супроводжуються. Дане повідомлення застосовується для передачі даних про радіолокаційні цілі, що відслідковуються, у стиснутому форматі. Це дозволяє передавати дані багатьох цілей с мінімальним використанням трафіку. Мітки для нових цілей передаються повідомленнями типу TLB.

Формат дозволяє передавати дані чотирьох цілей в одному блоці. 
Приклад формату повідомлення TTD виглядає наступним чином (рис. 2):

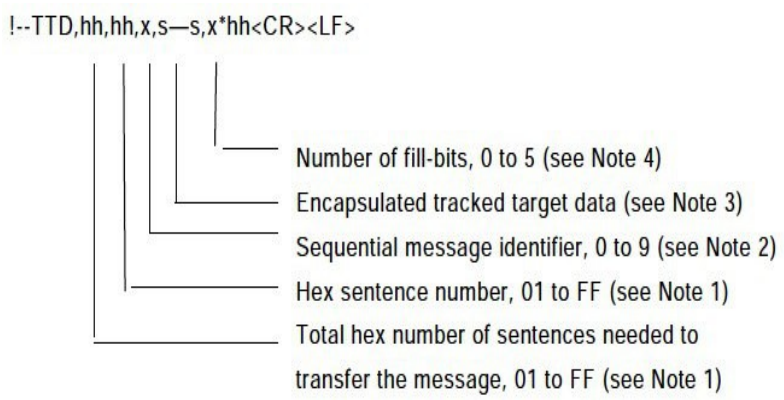

Рис. 2. Формат повідомлення ТТМ Джерело: [17, С. 114].

Примітки (Note) вказані на рис. 2 визначають наступне:

Примітка 1: для передачі даних всіх цілей, що відслідковуються, може знадобитися передача складеного речення. Перше поле визначає загальну кількість пропозицій, які використовуються для повідомлення, мінімальне значення 1. Друге поле визначає порядок цього речення в повідомленні, мінімальне значення 1. Це не можуть бути порожні поля.

Примітка 2: ідентифікатор послідовного повідомлення надає ідентифікаційний номер повідомлення від 0 до 9, який призначається послідовно і збільшується для кожного нового повідомлення 3 складеними реченнями. Лічильник скидається до 0 після використання 9. Для повідомлення, що вимагає використання складеного речення, кожне речення повідомлення містить один і той же послідовний ідентифікаційний номер повідомлення. Він використовується для ідентифікації речень, що містять частини одного і того ж повідомлення. Це допускає можливість того, що інші речення можуть чергуватися з реченнями повідомлення, які, будучи взяті разом, складають одне повідомлення. Це повинно бути пусте поле для повідомлень, які поміщаються в одне речення.

Примітка 3: структура даних цілі, що відстежується, описана в табл. 1. Дані зберігаються в першу чергу в найважливішому біті. Кожен символ повідомлення перетвориться в шість бітів. Одне речення може містити від однієї до чотирьох структур з 15 символів в одному реченні. Це поле підтримує максимум 60 дійсних символів для повідомлень, складених 3 кількох речень.

Примітка 4: це не може бути пусте поле. Це поле представляє кількість бітів заповнення, доданих для заповнення останнього шестирозрядного кодованого символу. Це поле є обов'язковим і повинно негайно слідувати за полем стиснутих даних. Для стиснення число двійкових бітів має бути кратним шести. Якщо ні, додається від одного до п’яти бітів заповнення. Це поле має бути встановлене на нуль, коли не були додані біти заповнення.

Поле бітів заповнення завжди має бути останнім полем даних у реченні.

Таблиця 1

Структура даних цілі, що відстежується

\begin{tabular}{|c|c|c|c|c|c|}
\hline Параметр & $\begin{array}{c}\text { К- } \\
\text { сть } \\
\text { бітів }\end{array}$ & $\begin{array}{c}\text { Діапазон } \\
\text { та роз- } \\
\text { дільна } \\
\text { здатність }\end{array}$ & & Опис & \\
\hline $\begin{array}{c}\text { Версія } \\
\text { протоколу }\end{array}$ & 2 & від 0 до 3 & $\begin{array}{l}\text { Версія пр } \\
\text { встановле } \\
\text { визначено } \\
\text { зервовані } \\
\text { цієї струк }\end{array}$ & $\begin{array}{l}\text { токолу завжди } \\
\text { на на нуль д } \\
\text { ї нижче. Інші } \\
\text { для подальшо } \\
\text { гури. }\end{array}$ & $\begin{array}{l}\text { I повинна бути } \\
\text { ля структури, } \\
\text { значення заре- } \\
\text { оі модифікації }\end{array}$ \\
\hline $\begin{array}{l}\text { Номер } \\
\text { цілі }\end{array}$ & 10 & $\begin{array}{c}\text { від } 0 \text { до } \\
1023\end{array}$ & $\begin{array}{l}\text { Номер ціл } \\
\text { повідним } \\
\text { цілі заре } \\
\text { відстежен }\end{array}$ & $\begin{array}{l}\text { ri, пов'язаний з } \\
\text { номером. Ну. } \\
\text { ервований длs } \\
\text { ня }\end{array}$ & $\begin{array}{l}\text { міткою з від- } \\
\text { льовий номер } \\
\text { жодної цілі }\end{array}$ \\
\hline $\begin{array}{c}\text { Істинний } \\
\text { пеленг }\end{array}$ & 12 & $\begin{array}{l}\text { до } 359,9^{\circ} \\
\text { крок } 0,1^{\circ}\end{array}$ & $\begin{array}{l}\text { Для } \quad \text { пів } \\
409,5^{\circ}=\mathrm{H}\end{array}$ & $\begin{array}{l}\text { нічної систем } \\
\text { едійсні або нед }\end{array}$ & $\begin{array}{l}\text { и координат } \\
\text { оступні дані }\end{array}$ \\
\hline Швидкість & 12 & $\begin{array}{c}\text { до 409,4 } \\
\text { вузла } \\
\text { крок } 0,1 \\
\text { вузол }\end{array}$ & $\begin{array}{l}\text { Для швид } \\
\text { стабілізац } \\
\text { 409,5 вузл } \\
\text { дані }\end{array}$ & $\begin{array}{l}\text { ¿кісного режим } \\
\text { iї } \\
\text { ів = Недійсні а }\end{array}$ & $\begin{array}{l}\text { му та режиму } \\
\text { бо недоступні }\end{array}$ \\
\hline Курс & 12 & $\begin{array}{l}\text { до } 359,9^{\circ} \\
\text { крок } 0,1^{\circ}\end{array}$ & $\begin{array}{l}\text { Для шви } \\
\text { стабілізац } \\
409,5^{\circ}=\text { н }\end{array}$ & $\begin{array}{l}\text { Ікісного режим } \\
\text { iї } \\
\text { едійсні або нед }\end{array}$ & $\begin{array}{l}\text { му та режиму } \\
\text { оступні дані }\end{array}$ \\
\hline $\begin{array}{l}\text { Напрямок } \\
\text { (лише для } \\
\text { AIS цілей) }\end{array}$ & 12 & $\begin{array}{l}\text { до } 359,9^{\circ} \\
\text { крок } 0,1^{\circ}\end{array}$ & $\begin{array}{l}\text { Повідомл } \\
\text { АІС, півні } \\
409,4^{\circ}=\mathrm{H} \\
409,5^{\circ}= \\
\text { локаційно }\end{array}$ & $\begin{array}{l}\text { ений напрямо } \\
\text { чна система ко } \\
\text { едійсні або нед } \\
\text { відсутні дані, } \\
\text { го спостережен }\end{array}$ & $\begin{array}{l}\text { к за даними } \\
\text { ординат } \\
\text { Іоступні дані } \\
\text { ціль від радіо-- } \\
\text { гня }\end{array}$ \\
\hline \multirow{9}{*}{$\begin{array}{c}\text { Статус } \\
\text { цілі } \\
\text { РЛС/AIS }\end{array}$} & \multirow{9}{*}{3} & & Значення & РЛС & AIS \\
\hline & & & 000 & $\begin{array}{c}\text { Не відстежу- } \\
\text { ється }\end{array}$ & $\begin{array}{c}\text { Дані про ціль } \\
\text { відсутні }\end{array}$ \\
\hline & & & 001 & $\begin{array}{c}\text { Захоплення } \\
\text { цілі (не вста- } \\
\text { новлено) }\end{array}$ & Спляча ціль \\
\hline & & & 010 & Ціль втрачено & Ціль втрачено \\
\hline & & & 011 & Зарезервовано & Зарезервовано \\
\hline & & & 100 & $\begin{array}{c}\text { Відстеження } \\
\text { встановлено, } \\
\text { без тривоги }\end{array}$ & $\begin{array}{c}\text { Ціль активо- } \\
\text { вана, без } \\
\text { тривоги }\end{array}$ \\
\hline & & & 101 & Зарезервовано & Зарезервовано \\
\hline & & & 110 & $\begin{array}{c}\text { Відстеження } \\
\text { встановлено, } \\
\text { НТЗ/ЧНТЗ*) } \\
\text { тривога }\end{array}$ & $\begin{array}{c}\text { Ціль активо- } \\
\text { вана, } \\
\text { НТЗ/ЧНТЗ } \\
\text { тривога }\end{array}$ \\
\hline & & & 111 & $\begin{array}{c}\text { Відстеження } \\
\text { встановлено, } \\
\text { підтверджено } \\
\text { НТЗ/ЧНТЗ } \\
\text { тривогу }\end{array}$ & $\begin{array}{c}\text { Ціль активо- } \\
\text { вана, підтвер- } \\
\text { джено } \\
\text { НТЗ/ЧНТЗ } \\
\text { тривогу }\end{array}$ \\
\hline
\end{tabular}

Джерело: розроблено авторами за даними [17, С. 88].

*) найближча точка зближення/час до найближчої точки зближення.

У сучасних вимогах IMO до РЛС перелік обов'язкових повідомлень видачі даних по цілям у зовнішні споживачі спирається на поточну версію стан- 
дарту [17]. Зокрема, зазначено, що радіолокаційна система повинна надавати дані цілі, що супроводжуються, через послідовний інтерфейс для передачі на інше навігаційне обладнання, використовуючи повідомлення TTD [14]. Нові асоційовані цілі повідомляються за допомогою повідомлення TLB [17]. 3 метою унікальної ідентифікації суднових та берегових засобів зв'язку (станцій) для цифрових вибіркових викликів, застосовується серія з дев'яти цифр, що в цифровій формі передається по відповідному радіоканалу. Дана серія носить назву “ідентифікатор морської рухомої служби” (Maritime Mobile Service Identity, далі - MMSI). Якщо доступна інформація MMSI, вона повинна бути включена до повідомлень TLB. Рекомендованим полем TLB “Мітка, призначена на ціль “ $n$ ” для MMSI $123456789 є$ "MMSI = 123456789”.

Оскільки формат повідомлення TTD з'явився у стандарті відносно недавно (в останній, четвертій його редакції), то його підтримку реалізовано лише у сучасних моделях НРЛС. В основній же масі НРЛС, які встановлені на кораблях ВМС ЗС України, використовуються виключно ТТМ повідомлення, повідомлення ж нового типу TTD майже не застосовуються.

Тому, берегова підсистема прийому та інтеграції даних від сенсорів системи спостереження за надводною обстановкою MSA повинна підтримувати цілий набір стандартних інтерфейсів для інтеграції даних від віддалених корабельних НРЛС. Обробка повідомлень TLB, TLL, TTM, TTD стандартів [17-18] - це мінімально необхідний набір.

Здійснення переконвертування даних про цілі на автосупроводженні $з$ повідомлень TLB, TLL, TTM, TTD в інший формат (чи протокол) безпосередньо на кораблі також доволі дієвий варіант. При цьому, критерієм доцільності виконання такого переконвертування стандартних форматів даних НРЛС в інший формат/протокол може служити досягнення більш ефективної передачі даних по радіоканалу “корабель-берег” в новому протоколі. Критерії доцільності вибору того чи іншого формату передачі даних по радіоканалу можуть бути різними: завадостійкість та стійкість до впливу РЕБ, мінімізація обсягу даних, що передаються тощо. Так, зокрема, склад каналоутворюючого обладнання та транспортні протоколи накладають свої обмеження на організацію транспортування даних в каналі. А переформатування низки повідомлень ТТМ про кілька автосупроводжуємих цілей за один оберт антени в одне складене повідомлення TTD, значно мінімізує обсяг даних, що передаються. Даний критерій доцільності особливо гостро постає при використанні “повільного” короткохвильового радіоканалу.

Ще більше зменшити навантаження на повільний канал дозволить адаптація темпу передачі пові- домлення TTD з поточними характеристикам маневрування цілей. Темп передачі тоді визначається найбільшою 3 швидкостей цілей, що супроводжуються, та підвищується у разі виявлення маневру курсом будь-якої з них. Максимальний темп передачі становить один раз за оберт антени.

До РЛС для малогабаритних/прогулянкових суден не висуваються спеціальні вимоги та не існує окремого стандарту виконання. Виробники спираються на загальні вимоги стандартів IMO для радарів та кращу практику, що склалась.

Особливості застосування НРЛС на малорозмірних судах $з$ низькою надбудовою та малогабаритним містком, “де-факто” накладають власну специфіку на вимоги щодо потужності, формату зондуючого імпульсу та інших параметрів, включаючи організацію інформаційної взаємодії цих РЛС з іншими сенсорами та зовнішніми пристроями.

Особливість сучасних радарів такого типу полягає в моноблочності їх архітектури та управлінні ними через інтерфейс Ethernet. Доступ до функціоналу програмного додатку, шляхом якого здійснюється управління моноблочними радар-сенсорами, зазвичай реалізовано з використанням багатофункціонального дисплею (Multi-functional display, далі MFD). Сам додаток і протокол взаємодії з радарсенсором, як правило, пропрієтарні. Наприклад, фірмові мережеві протоколи "Navnet TZTouch", "SeaTalk", тощо.

На кораблях та суднах ВМС ЗС України РЛС подібного типу набули широкого розповсюдження. Зазвичай, до багатофункціонального дисплею, крім РЛС, підключені також інші сенсори. Основний обмін інформацією між пристроями виконується через iнтерфейс Ethernet. Підключення MFD до навігаційних датчиків 3 цифровими виходами за протоколами NMEA0183 (стандарт, який визначає як електричні так і функціональні характеристики комунікаційного протоколу для обміну інформацією між пристроями морського електронного обладнання) та/або NMEA2000 (стандарт зв'язку “plug-and-play”, який використовується для підключення морських сенсорів та індикаторних блоків на кораблях і катерах) реалізовано напряму або через відповідні конвертори [19]. Як зазначалось вище, радарний сенсор, інтегровані багатофункціональні дисплеї MDF та інше обладнання платформ, яке було розроблене для цивільних яхт та катерів, як правило взаємодіє через локальну мережу за пропрієтарними протоколами. Так, наприклад, для РЛС малих броньованих артилерійських катерів (далі - мбака) пр. 58155 це протокол "Navnet TZTouch" від фірми-виробника FURUNO.

Власне, вивчення та аналіз документації, а також практичне спостереження за роботою радіолокаційного обладнання маломірних суден, які не пот- 
рапляють під конвекційні вимоги IMO щодо радіоелектронного обладнання, передбачувано підтвердили загальні особливості функціонування моноблочних радар-сенсорів для суден такого типу:

- у зв'язку з відсутністю стандартів побудови, виробники спираються на вимоги стандартів IMO для РЛС в частині параметрів та функцій, що реалізуються;

- ARPA у складі РЛС для маломірного флоту має назву MARPA (mini ARPA). MARPA спроможні супроводжувати до 10 цілей одночасно та допускають захоплення виявлених цілей на автосупроводження виключно в ручному режимі. Показники точності та якості автосупроводження захоплених цілей у MARPA гірші, ніж у ARPA;

- інтерфейси взаємодії з зовнішнім обладнанням, архітектура, потужність і тип зондуючого сигналу обираються виробниками виходячи 3 практики застосування, що склалась на малорозмірних суднах. Це призводить до необхідності аналізувати можливості кожної конкретної специфікації РЛС такого типу;

- через низку особливостей основних платформ застосування (малорозмірні судна), розвиток отримали мережеві інтерфейси (CAN, Ethernet) міжприладової інформаційної взаємодії (зокрема, й для передачі Radar Video), які, в масі своїй, є пропрієтарними.

Таким чином, вибір конкретного варіанту комплектації неконвенційних радар-сенсорів для встановлення на платформи ВМС ЗС України потребує спеціального аналізу функціональних можливостей комплекту радіолокаційного обладнання, що планується до інсталяції. Предметом аналізу повинна стати наявність у ньому технічної можливості передачі повідомлень про радіолокаційні цілі, що супроводжуються, у зовнішні системи в стандартних форматах TTM та TTD через стандартний протокол, передбачений вимогами IMO до суднових РЛС. Так, наприклад, проведення такого аналізу щодо можливості включення мбака пр. 58155 до складу корабельної компоненти інтегрованої системи спостереження за надводною обстановкою, показав, що в існуючий комплектації радіолокаційного обладнання катера така інтеграція виявилась неможливою через обмеження, накладені пропрієтарним протоколом обміну виробника.

\section{Висновки}

Виходячи із зазначеного вище, можна зробити наступні висновки:

1. Корабельні РЛС, які плануються включати в систему спостереження за надводною обстановкою у якості сенсорів, повинні мати вбудований модуль САРП якій підтримує наступні вбудовані базові функції:

- захоплення цілі на автосупроводження;

- автосупроводження цілей;

- видача інформаційних повідомлень (формуляру) з параметрами руху цілей до зовнішніх пристроїв в форматі повідомлень ТTM або TTD стандарту IEC 61162-1:2016 [17].

2. Функціонування модулів САРП регламентовано лише на самому загальному рівні. Стійкість алгоритмів автосупроводження під час маневрів курсом та швидкістю (як цілі, так і власного корабля), вплив хвилювання моря та завад для конкретних корабельних РЛС потребують перевірки на натурних випробуваннях.

У якості перспективи розвитку розглянутого напрямку дослідження, з метою подальшого підвищення обізнаності про морську обстановку шляхом нарощування кількості сенсорів, вважається за доцільне розглянути питання задіяння берегових РЛС радіотехнічних постів берегової систем спостереження за надводною обстановкою ВМС ЗС України та вивчення питання організації їх інформаційної взаємодії на інструментальному рівні.

\section{Список літератури}

1. Указ Президента України “Про Концепцію розвитку сектору безпеки і оборони України № 92/2016 від 14.03.2016 p.” [Електронний ресурс]. - Режим доступу: https://zakon.rada.gov.ua/laws/show/92/2016\#Text/.

2. Розпорядження Кабінету Міністрів України “Про схвалення стратегії інтегрованого управління кордонами на період до 2025 року № 687-р від 24.07.2019 p.” [Електронний ресурс]. - Режим доступу: https://zakon.rada.gov.ua/laws/show/687-2019-\%D1\%80\#n279.

3. Мазур В.Ю. Методичні основи оцінки ефективності функціонування єдиної системи висвітлення надводної обстановки на морській ділянці / В.Ю. Мазур, О.В. Боровик // Наука і техніка Повітряних Сил Збройних Сил України. 2018. - № 2(31). - C. 182-189. https://doi.org/10.30748/nitps.2018.31.24.

4. Weintrit A. The Electronic Chart Display and Information System (ECDIS): An Operational Handbook / A. Weintrit. London: Taylor \& Francis Group, 2009. - 1136 p. https://doi.org/10.1201/9781439847640.

5. Мазур В.Ю. Аналіз систем висвітлення надводної обстановки морських держав / В.Ю. Мазур, Р.В. Алієв // Збірник наукових праць Харківського національного університету Повітряних Сил. - 2018. - № 1(55). - С. 116-121. https://doi.org/10.30748/zhups.2018.55.16.

6. Ponsford A.M. Radars for Maritime Domain Awareness / A.M. Ponsford // Conference "Military Radar Summit, Arlington (VA)”. - Virginia, February 2015. http://dx.doi.org/10.13140/RG.2.1.3961.7687. 
7. Горобцов А.П. Сопоставление судовых радаров, работающих в S-, X-, К- диапазонах / А.П. Горобцов, А.Н. Маринич, Ю.М. Устинов // Вестник Государственного университета морского и речного флота имени адмирала С.О. Макарова. - 2018. - № 5(51). - С. 1087-1093. https://doi.org/10.21821/2309-5180-2018-10-5-1087-1093.

8. Bole A.G. Radar and ARPA Manual: Radar, AIS and Target Tracking for Marine Radar Users (3rd edition) / A.G. Bole, Alan D. Wall, Andy Norris. - Oxford, United Kingdom: Elsevier Science \& Technology, 2014. - 552 p.

9. Is ARPA Suitable for Automatic Assessment of AIS Targets? / F. Heymann, T. Noack, P. Banyś, E. Engler // Marine Navigation And Safety Of Sea Transportation, Germany. - 2013. - P. 223-232. https://doi.org/10.1201/b14961-40.

10. Wawruch R. Comparative Analysis of the Usefulness of AIS and ARPA for Anti-collision Purposes and Detection of Ship Manoeuvres / R. Wawruch // International Conference on Transport Systems Telematics. - TST 2019: Development of Transport by Telematics. - P. 346-360. https://doi.org/10.1007/978-3-030-27547-1_25.

11. Berking B. Stabilizing the Radar Picture and ARPA Data / Bernhard Berking, Joachim Pfeiffer. - Cambridge: Published online by Cambridge University Press, 2009. - 52 p. https://doi.org/10.1017/S0373463300012479.

12. The official site IMO.ORG. Resolution A.823(19) adopted on 23 November 1995. Performance Standards For Automatic Radar Plotting AIDS. - Available at: https://goo.su/31nm.

13. The official site IMO.ORG. Resolution MSC.192(79) Annex 34. Revised Recommendation On Performance Standards For Radar Equipment Index. - Available at: http://www.imo.org/en/KnowledgeCentre/IndexofIMOResolutions/Maritime-SafetyCommittee-(MSC)/Documents/MSC.192(79).pdf.

14. The official site IEC.CH. IEC 62388:2013. Maritime navigation and radiocommunication equipment and systems Shipborne radar - Performance requirements, methods of testing and required test results. - Available at: https://webstore.iec.ch/publication/6967.

15. The official site IEC.CH. IEC 60872:1999. Maritime navigation and radiocommunication equipment and systems - Radar plotting aids -Part 1:Automatic radar plotting aids (ARPA) -Methods of testing and required test results. - Available at: https://webstore.iec.ch/p-preview/info_iec60872-2\%7Bed1.0\%7Den.pdf.

16. The official site IEC.CH. IEC 60936-1:1999. Maritime navigation and radiocommunication equipment and systems Radar - Part 1: Shipborne radar - Performance requirements - Methods of testing and required test results. - Available at: https://webstore.iec.ch/ The official site сайт IEC.CH. IEC 61162-1:2016.

17. The official site WEBSTORE.IEC. Maritime navigation and radiocommunication equipment and systems - Digital interfaces - Part 1: Single talker and multiple listeners. - Available at: https://webstore.iec.ch/publication/25754.

18. The official site IEC.CH. IEC 61162-450:2018. Maritime navigation and radiocommunication equipment and systems Digital interfaces - Part 450: Multiple talkers and multiple listeners - Ethernet interconnection. - Available at: https://webstore.iec.ch/publication/28704.

19. The official site FURUNOUSA.COM. Operation manuals model TZT9/TZT14/TZTbb. - Available at: https://goo.su/31Ni.

Надійшла до редколегії 02.09.2020

Схвалена до друку 13.10.2020

\section{Відомості про авторів:}

Коновець Віктор Іванович

кандидат технічних наук старший науковий співробітник провідний науковий співробітник

Інституту Військово-Морських Сил

Національного університету “Одеська морська академія”, Одеса, Україна

https://orcid.org/0000-0002-5354-4234

Смиринська Наталія Борисівна

провідний науковий співробітник науково-дослідного центру Збройних Сил України

“Державний океанаріум”,

Одеса, Україна

https://orcid.org/0000-0001-5373-2625

\section{Information about the authors:}

Viktor Konovets

Candidate of Technical Sciences Senior Research

Lead Research

of the Naval Institute

of the National University “Odessa Maritime Academy”, Odesa, Ukraine

https://orcid.org/0000-0002-5354-4234

\author{
Nataliia Smyrynska \\ Lead Research \\ of the Scientific Research Center \\ of the Armed Forces of Ukraine "State Oceanarium", \\ Odesa, Ukraine \\ https://orcid.org/0000-0001-5373-2625
}

\title{
ПУТИ ПОВЫШЕНИЯ ПРОИНФОРМИРОВАННОСТИ О МОРСКОЙ ОБСТАНОВКЕ ЗА СЧЕТ ИНТЕГРАЦИИ КОРАБЕЛЬНЫХ НАВИГАЦИОННЫХ РЛС В СИСТЕМУ ОСВЕЩЕНИЯ НАДВОДНОЙ ОБСТАНОВКИ
}

\author{
В.И. Коновец, Н.Б. Смиринская
}

В статье приведены результаты анализа вопросов практической интеграции данных от навигационных РЛС корабельной компоненты ВМС ВС Украинь в систему освещения надводной обстановки. С учетом этого анализа разработаны рекомендации по выбору вариантов комплектации навигационных РЛС, планируемых к установке на современные и перспективные морские платформы с иелью обеспечения их дальнейшей интеграции в систему освещения надводной обстановки. 
Ключевые слова: проинформированность (осведомленность) о морской обстановке, система освещения надводной обстановки, навигаиионные РЛС, система автоматической радиолокационной прокладки (САРП), сообщение обмена информацией, ВМС ВС Украины.

\title{
WAYS TO INCREASE MARITIME AWARENESS BY INTEGRATING SHIPBORNE NAVIGATION RADARS INTO THE MARITIME SITUATIONAL AWARENESS SYSTEM
}

\author{
V. Konovets, N. Smyrynska
}

The relevance of the research, placed in this article, raised by the necessity of design a modern maritime monitoring system which will provide the implementation of several State bodies' decisions in area of maritime domain security. One of the significant constituent parts of the Maritime Domain's Awareness (MDA), which provides a prompt response on changes in it - it's upto date, on-line and constantly upgrading Maritime Situational Awareness system (MSAS). An analysis of recent studies and publications on the experience of building and organizing MSASs of the leading countries of the world indicates that today these systems are the basis for building an overall Maritime Security System (MSS) for these countries. MSS includes the entire range of sources (ship, air, space and land-based radars) for obtaining Maritime Security Information (MSI) to ensure complete Maritime Situational Awareness (MSA) in order to get the ability to achieve the full-size MDA. Thus, the issue of including and full integration the navigational radars of combat ships' and auxiliary vessels of the Ukrainian Naval Forces to the mentioned system is becoming more and more urgent in order to raise the MSA by increasing the number of these sensors which are the data's suppliers for the MSAS. Therefore, the main subject of the article is the analysis of the ways of practical integration of navigation radars' data of the surface platforms of Ukrainian Naval Forces in the State's Common Maritime Surveillance Information System. The article includes recommendations for the requirement to the navigation radars, which are planned to be installed on currently existing and perspective platforms with the possibility of their further integration into the system. The article defines the minimum list of required basic built-in functions, and finds that the lack of support for any of them makes impractical including the navigation radar into the MSAS as a full-fledged sensor. Also, the method of preliminary assessment of the suitability of the navigation radar for further integration into the system is substantiated. This method based on the assessment of the presence or absence of an integrated system of Automatic Radar Plotting Aid (ARPA).The article describes the complexity of the problem of integrating ship's navigation radars into the MSAS due to the two main factors. Firstly, the system in relation to the radar is a remote consumer with access through a radio channel. Secondly, the built-in specialized software or standard interfaces of the existing navigation radars, as a rule, cannot be upgraded or optimized for the MSIS tasks or restrictions imposed by the features of the radio channel. Thus, the main integration efforts should be aimed at adapting the existing radars' information outputs interfaces. In summary in the article makes the conclusion that the onshore subsystem of receiving data from the MSIS sensors should be able to operate with the set of the standard interfaces for integrating data from remote ship radars. The minimum required to the standard interfaces is the support of the TLB, TLL, TTM and TTD messages in according with the International Maritime Organization standards, namely: IEC 61162-1 and IEC 61162-450. Thus, shipborne radars, which are planned to be included in the surface surveillance system as sensors, must have a built-in ARPA module which supports the following built-in basic functions, namely: target acquisition for auto tracking; auto-tracking of targets; issuance of information messages with parameters of target movement to external devices in the format of TTM or TTD messages according to the IEC 61162-1: 2016 standard. Also, the functioning of ARPA modules is regulated only at the most general level. The stability of the algorithms for auto-tracking during maneuvers with the course and speed (both the target and the own ship), the effect of sea waves and interference for specific shipborne radar stations require verification on full-scale tests.

Keywords: Maritime Situational Awareness, maritime situational awareness system (MSAS), navigational radars, Automatic Radar Plotting Aid (ARPA), information exchange message, Ukrainian Naval Forces. 